\title{
Research on Sino-Russian Trade Potential Based on Gravity Model
}

\author{
Weijian Li, Chenggang $\mathrm{Li}^{*}$ \\ Business School, Beijing Institute of Fashion Technology, Beijing, China \\ Email: *ccid205@126.com
}

How to cite this paper: Li, W. J., \& Li, C. G. (2021). Research on Sino-Russian Trade Potential Based on Gravity Model. Modern Economy, 12, 1805-1816.

https://doi.org/10.4236/me.2021.1212093

Received: November 4, 2021

Accepted: December 14, 2021

Published: December 17, 2021

Copyright $\odot 2021$ by author(s) and Scientific Research Publishing Inc. This work is licensed under the Creative Commons Attribution International License (CC BY 4.0).

http://creativecommons.org/licenses/by/4.0/ (c) (i) Open Access

\begin{abstract}
The importance of bilateral trade for the economic development of China and Russia, as globally influential and neighboring countries, cannot be overstated. The trade between China and Russia is growing in scale, and the trade structure is being optimized, and the economic ties between the two countries are increasing. Combining the analysis of bilateral trade data between China and Russia in the post-financial crisis period and using the trade gravity model as a research model, this paper briefly analyzes the trade potential on the basis of the current situation of China-Russia trade and finds that bilateral trade is closely related to GDP and there is still scope for expansion of bilateral trade potential between China and Russia. The paper makes suggestions on how to explore the trade potential of both China and Russia in several aspects.
\end{abstract}

\section{Keywords}

Sino-Russian Bilateral Trade, Gravity Model, Trade Potential

\section{Introduction}

During President Xi Jinping's visit to Russia and participation in the St. Petersburg Economic Forum in early June 2019, the two sides announced the upgrading of Sino-Russian relations to a new era of comprehensive strategic partnership of cooperation. Since the formal establishment of the strategic partnership in 1996, China and Russia have been cooperating closely in the political, economic and diplomatic fields, and both countries are considered to be very important emerging economic developing countries in the world and belong to the BRICKS (BRICS) countries. In the last decade, bilateral trade has been making new breakthroughs. First, the two countries share a common border of more 
than $4370 \mathrm{~km}$, which gives them a natural geographical advantage. Secondly, both countries are upholders and practitioners of multilateralism, and they consult and cooperate in international and regional affairs, which create a favorable external environment for bilateral trade. 2020-2021 Russian-Chinese Year of Science and Technology Innovation is the first national year after the new era of Russian-Chinese relations, which means further strengthening of innovation cooperation between the two sides. This paper combines the qualitative and quantitative analysis of the latest data and uses gravitational models to analyze the trade potential between China and Russia. As the economic and trade relations between China and Russia are developing rapidly and the bilateral trade volume keeps growing rapidly, it is of great practical significance to study and analyze the bilateral trade potential of China and Russia in order to explore the bilateral trade potential.

The article is organized as follows: firstly, the scale and structure of Sino-Russian bilateral trade in the post-financial crisis period are analyzed, secondly, the impact of the two countries' GDP, distance and direct investment on the trade volume of the two countries is analyzed by the extended gravity model, and then the trade potential of China and Russia is analyzed.

\section{Research Status of Sino-Russian Trade}

Regarding the research on the potential of bilateral trade between China and Russia, Yang (2009) argued that China-Russia trade is highly complementary and the development of bilateral trade depends largely on the strategic and international relations between the two countries. Liu \& Yin (2016) analyzed the development of China-Russia trade mentions and argued that with the Belt and Road as an opportunity, bilateral economic and trade cooperation can be strengthened more, especially with the northeast region of China. Wan (2017) argued that the unreasonable trade structure and exchange rate have hindered the trade between China and Russia, resulting in smaller trade potential. Xu \& $\mathrm{Na}$ (2018) argue that the level of Sino-Russian economic and trade cooperation is not commensurate with the relationship and potential of the two countries. Sun (2020) believes that 2020 and 2021 are the years of science and technology innovation in China and Russia, and that they should jointly promote the development of e-commerce and biomedicine.

Regarding the research on the gravity model, Lin \& Wang (2004) established a gravity model suitable for China's bilateral trade situation by taking the traditional trade gravity model as the basis and adding or subtracting explanatory variables from the model considering the basic national conditions of China. Through the empirical tests and policy implications analysis using the gravity model, it is concluded that spatial distance, land area, and the main factors affecting China's bilateral trade. Sheng \& Liao (2004) used the gravity model to examine the determination of export trade flows of emerging market economies and estimated China's export potential to its major trading partners at both aggregate and sectoral levels. Their results show that China's exports are in general 
"over-traded". Gao (2008) used the gravity model to find the influential factors determining the trade between China and Russia and concluded that the trade between China and Russia needs to be activated by external factors. Huang (2016) studied the potential of Sino-Russian trade based on the gravitational force model and argued that China and Russia should improve institutional arrangements and cultivate emerging trade patterns. Li \& Yu (2018) analyzed the influencing factors of Sino-Russian trade by combining the gravitational model of trade and argued that Sino-Russian trade has a promising future.

The above relevant domestic research experience provides valuable experience for this research. On this basis, this paper argues that the bilateral trade between China and Russia is generally positive and has broad trade potential, and this paper will study the bilateral trade potential between China and Russia from the perspective of gravity model.

\section{The Status Quo of Sino-Russian Trade}

\subsection{Scale Analysis}

Russian-Chinese relations play a key role in the Asia-Pacific region and in the world at large. These countries possess the characteristics of geographical proximity and complementary economic models. In Russia's foreign trade, China takes the lead in all categories: in terms of trade volume, imports and exports. (Figure 1)

The first trade cooperation between China and Russia started in 1992, and it has been nearly 20 years so far. 2014, when China and Russia signed an agreement to enter into a comprehensive strategic cooperative relationship, means that bilateral trade cooperation between China and Russia will bring new development opportunities under the active promotion of both sides. At present, the scale of China-Russia trade is expanding, and since the beginning of the 21st century, China-Russia trade has entered a phase of steady development, with the

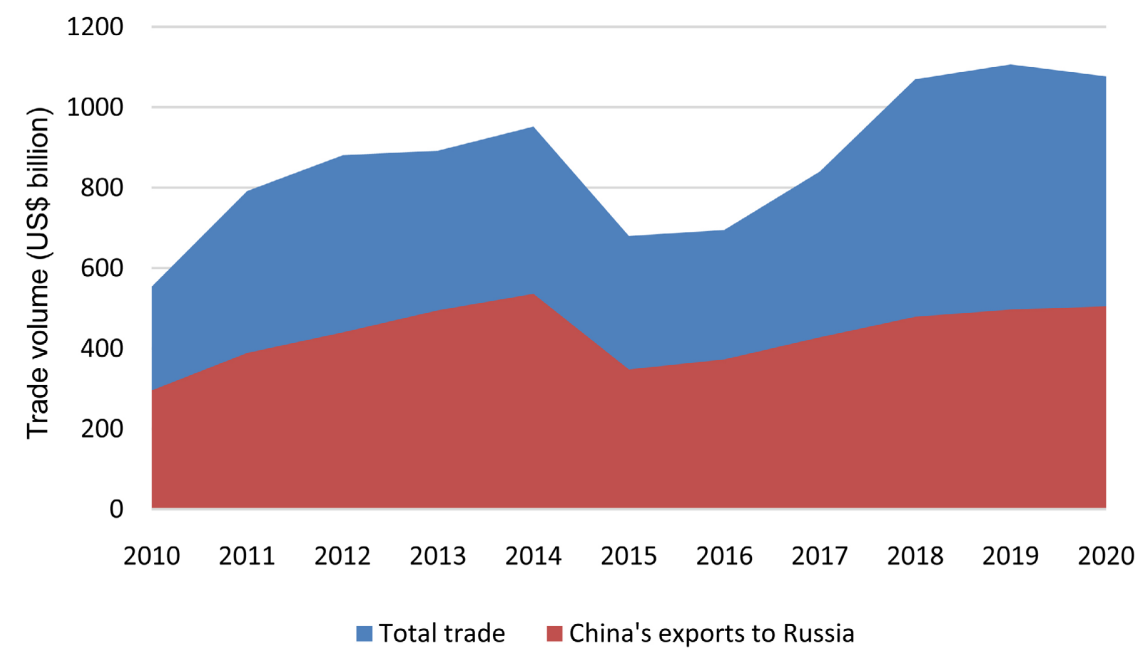

Figure 1. Trade volume between China and Russia from 2010 to 2020 (Source: Ministry of Commerce). 
cumulative trade scale exceeding USD 1000 billion from 2000 to 2020, with an annual growth rate of 18\%. 2019 China-Russia trade volume exceeded USD 110 billion, accounting for $2.32 \%$ of China's total foreign trade. 2010 was the first time that China became Russia's top trading country by 2020; China has become Russia's number one trading partner for the eleventh consecutive year (Figure 2).

1) China-Russia import and export trade resumes growth phase

In 2010-2014, total trade and imports and exports of China and Russia resumed the growth phase, with a significant decline in total volume and exports, while the decline in imports did not change significantly. The trade surplus gradually increased. Due to the financial crisis in 2008, our economic development was hampered, and by the end of 2009, our exports to Russia evaporated by nearly $\$ 15$ billion, down $47 \%$ year-on-year, a huge drop. The Russian government used $\$ 200$ billion to support the rate of the ruble to stabilize the exchange rate and stimulate the domestic economy, making Russia less affected by the financial crisis, and by the end of 2009 China's imports from Russia fell by nearly $\$ 2.5$ billion, down $10.7 \%$ year-on-year, a smaller drop. Only in 2010 did China-Russia trade start to rise and the trade scale returned to a level close to that before the financial crisis, at $\$ 55.53$ billion, and for the first time China occupied the first place in the ranking of Russia's foreign trade partners. The total bilateral trade volume between Russia and China continued to grow in the following four years, reaching $\$ 95.29$ billion in 2014. The rapid recovery and growth of China-Russia import and export trade is due to, first, the signing of 15 agreements on bilateral political cooperation between China and Russia in 2010 to establish a strategic partnership, which enabled bilateral trade between the two countries to begin to resume growth and grow rapidly; second, Russia's

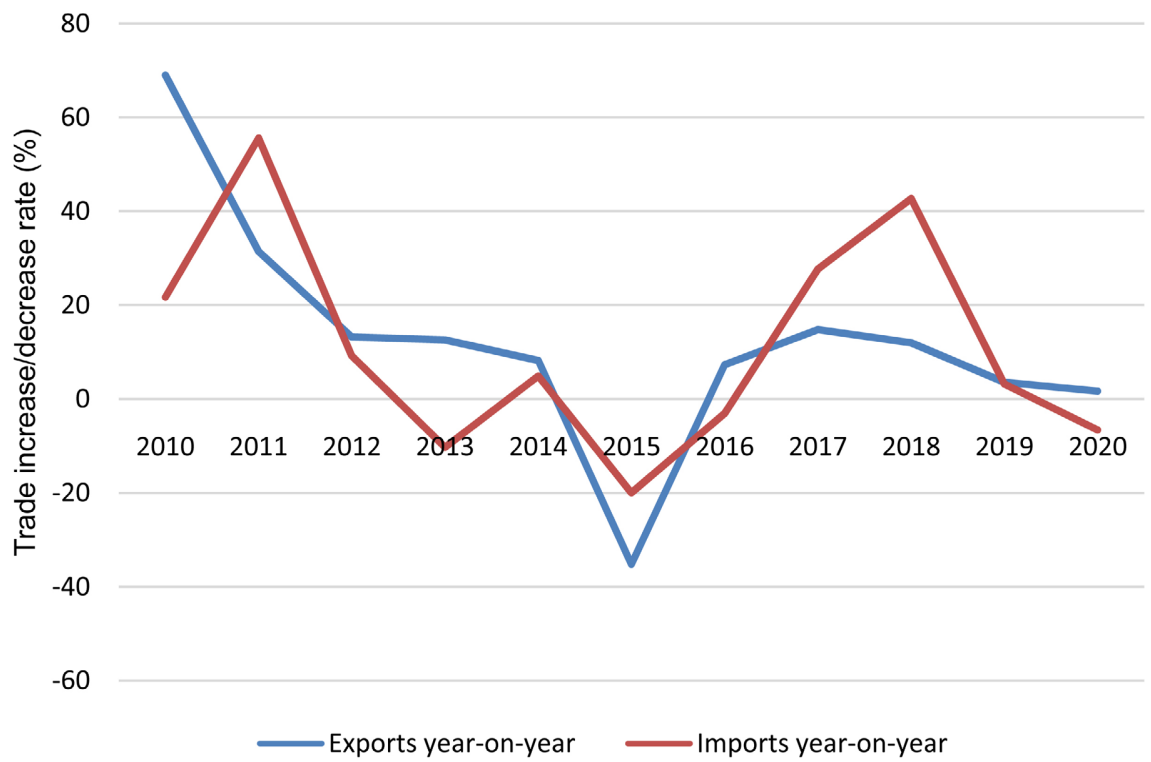

Figure 2. Year-on-year increase/decrease in bilateral trade between China and Russia from 2010 to 2020 (Source: Ministry of Commerce). 
accession to the WTO in 2012, along with the reduction of tariffs to international levels, which promoted a significant increase in China's exports to Russia, and political mutual trust and Tariff reduction has driven the continuous growth of total trade between China and Russia.

2) China-Russia import and export trade adjustment and strengthening stage

China-Russia trade saw a sharp decline in 2015, with total trade falling to $\$ 63.552$ billion, a $33.3 \%$ drop. China's exports and imports to Russia have correspondingly declined to varying degrees. The lack of international market demand and low prices of crude oil and other bulk foodstuffs, especially the low price of oil, hampered the development of the Russian economy, which relies on oil exports, while China's GDP growth rate slowed down in 2014, which combined led to massive shrinkage of Sino-Russian trade. 2016 and 2017 saw a recovery and increase in bilateral trade between China and Russia, and in 2019 bilateral trade between China and Russia again achieved a breakthrough to reach The main reason for the growth of total trade between China and Russia in 2015-2019 is the implementation of the "One Belt, One Road", in which China and Russia signed the "Agreement on the Construction of the Silk Road Economic Belt and the Eurasian Economic Union" in 2015. In 2017, China and Russia signed a joint statement on deepening the comprehensive strategic partnership, emphasizing the focus on the development strategy of China and Russia, promoting trade cooperation for mutual benefit.

\subsection{Commodity Structure Analysis}

1) Export commodity structure

In 2010, mineral products, wood and products and chemical products were the main products exported from Russia to China, with the combined export value of the three categories accounting for $77.5 \%$ of Russia's total exports to China. It is worth noting that although Russia's exports to China maintained growth, the growth of Russia's exports to China ranked low among its major export markets, which is related to the decline in the growth rate of Russia's exports of fossil fuels to China (Figure 3 ).

Russia exported $\$ 42.71$ billion of mineral products to China in 2018 , an increase of $61.9 \%$, accounting for $77.9 \%$ of Russia's total exports to China. Russia's mineral exports to China are mainly mineral fuels, mineral oils and their products, etc., which exported $\$ 41.22$ billion in 2018 , accounting for $73.5 \%$ of its total exports to China (Figure 4).

From 2010 to 2018, minerals have been the most important product exported from Russia to China, mainly energy resource-intensive products, with the share of exports increasing from $57 \%$ in 2010 to $73.5 \%$ in 2018 , showing a clear growth trend and a tendency to continue growing, occupying the first place in imports. This is followed by wood and products, with a decrease in exports, from $11 \%$ in 2010 to $6 \%$ in 2018.

Through the comparison of the proportion of various types of products in bilateral trade between China and Russia in 2010 and 2018, the composition of 


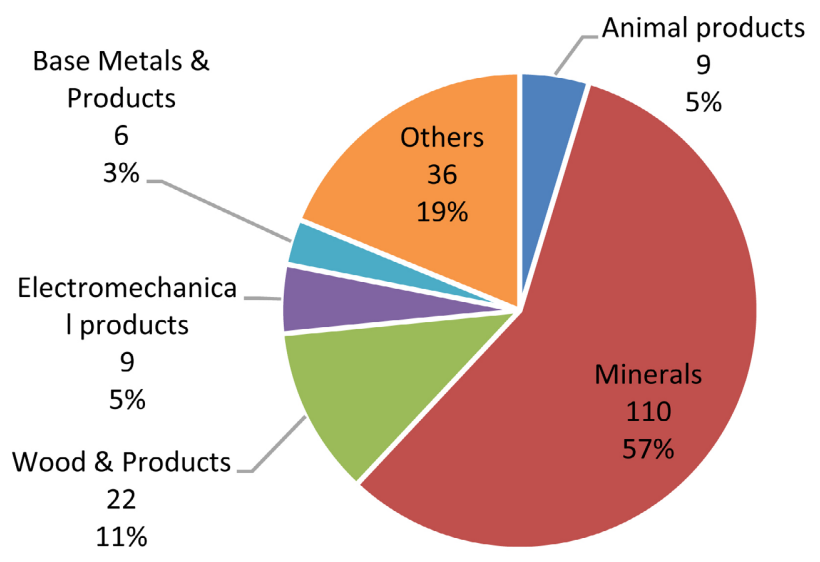

Figure 3. Composition of the main commodities exported from Russia to China in 2010 (Source: Ministry of Commerce).

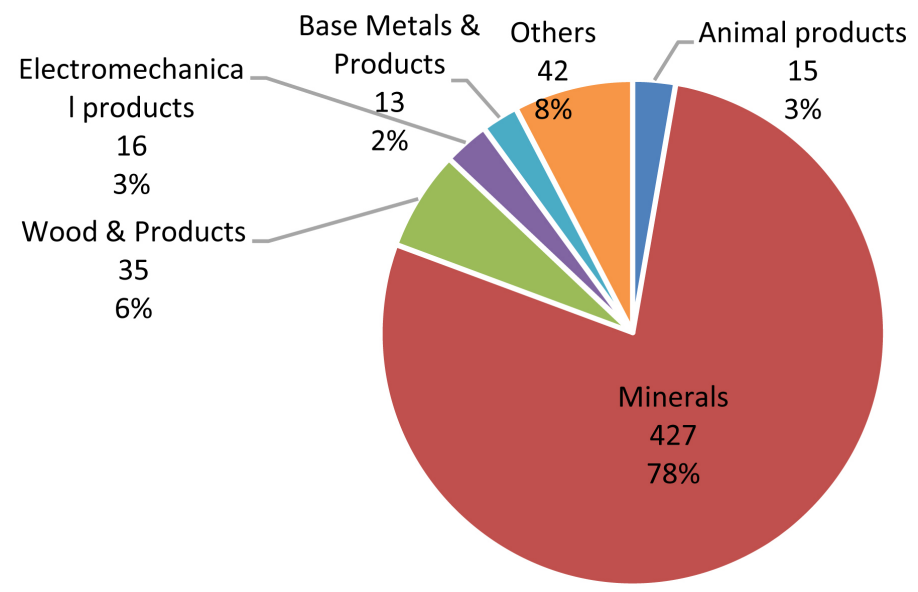

Figure 4. Composition of the main commodities exported from Russia to China in 2018 (Source: Ministry of Commerce).

Russia's exports to China in the post-financial crisis period is still focused on energy resource-intensive products, and in China-Russia trade, China is very dependent on Russia's energy resources, and the proportion of China's imports of mineral products is getting heavier. This also has certain disadvantages, Russia's export structure to China is single, and China's imports of Russia's main products are subject to Russia's control, once Russia restricts the export of energy products, China is bound to suffer a blow in energy supply.

2) Import commodity structure

Russia's main imports from China were electromechanical products, textiles and raw materials, and base metals and products, which together accounted for $\$ 24.30$ billion in 2010 (Figure 5), or $64.3 \%$ of Russia's total imports from China. The growth of Russia's imports from China was much higher than the growth of its exports to China, and also higher than the average growth of its imports. Among them, imports of transportation equipment, base metals and products more than doubled, and imports of mechanical and electrical products grew nearly double. 
Russia imported $\$ 26.45$ billion of electromechanical products from China in 2018, an increase of $3.9 \%$, accounting for $50.7 \%$ of Russia's total imports from China. China topped the Russian import market in seven categories of goods: electromechanical products, base metals and products, textiles and raw materials, furniture, toys and miscellaneous products, plastics and rubber, light industrial products such as shoes, boots and umbrellas, and optical watches and medical equipment.

As can be seen from the data from 2010 to 2018, electromechanical products have been the most important products imported by Russia from China, growing from $45 \%$ in 2010 to $51 \%$, with a year-on-year trend of increasing imports. More noteworthy is that the import value of chemical products has increased significantly in recent years, and the proportion has grown from 3\% to 5\% in 2018 (Figure 6).

Through the comparison of the share of various products in bilateral trade between China and Russia in 2010 and 2018, the structure of Russian imports from China has improved in the post-financial crisis period, with the reduction of Russian textile imports from China, the growth of electromechanical products, and the gradual transformation of labor-intensive products into capitaland technology-intensive products, mainly thanks to the optimization of China's

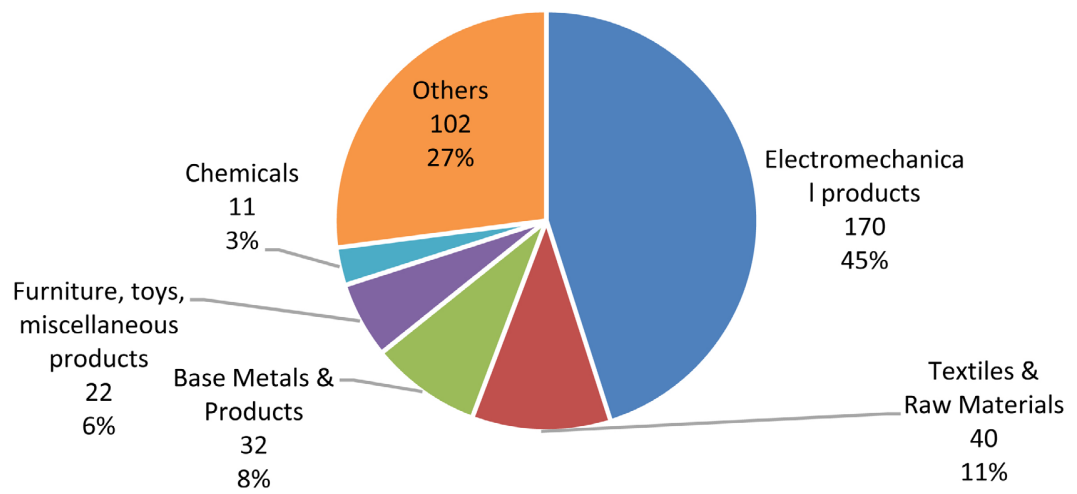

Figure 5. Composition of the main goods imported by Russia from China in 2010 (Source: Ministry of Commerce).

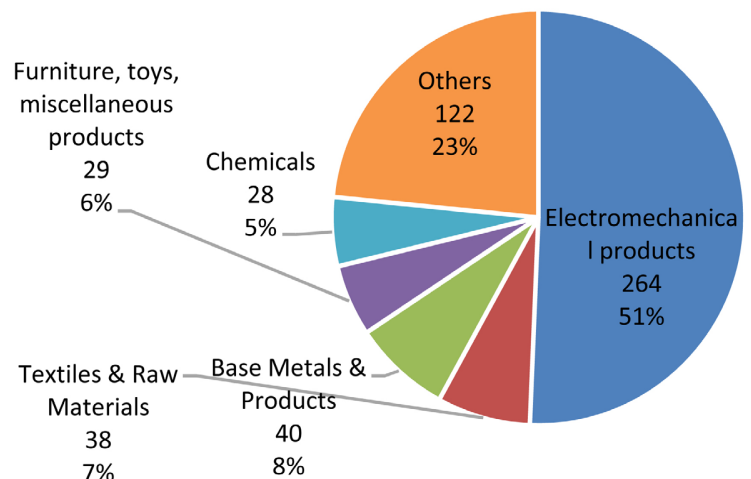

Figure 6. Composition of the main goods imported by Russia from China in 2018 (Source: Ministry of Commerce). 
foreign trade export structure, but also as a result of China's industrial The result of structural adjustment and increased investment in technology.

\section{Analysis of China-Russia Trade Potential Based on Gravity Model Perspective}

\subsection{Basics of Gravity Model}

The gravitational model of trade is an application of Newton's model of gravity in the economic field. The earliest application of the gravity model to the field of international trade was made by J. Tinbergen and Poyhonen in 1962 and 1963, respectively, who suggested that the individual trade flows between two economies are proportional to the size of their respective economies (generally expressed in terms of GDP) and inversely proportional to the distance between them. The basic form of the gravity model is:

$$
M_{i j}=k Y_{i} Y_{j} / D_{i j}
$$

Of which, $k$ is a constant, $M_{i j}$ denotes the trade volume between the two countries, $Y_{i}$ and $Y_{j}$ denote the economic size of the two countries respectively, which is generally expressed in terms of GDP, and $D_{i j}$ indicates the distance between the two countries, which generally refers to the distance between the economic centers or important ports of the two countries and represents the cost of trade.

The scale of national economy plays a decisive role in the degree of professional division of labor in international trade. The level of specialization of national production goods is high, then the trade commodity is relatively rich, the scale is also relatively large. The development of bilateral trade between nearby countries is more convenient, the greater the possibility of larger trade, according to the gravitational model proposed and used, its economic meaning is that the two countries' trade volume and commodity demand capacity are proportional to the relationship, distance inversely proportional.

\subsection{Model Building}

In the process of measuring the trade potential of Russia and China, the gravity model selects such variables as the GNP per capita of the importing country, the GDP of the exporting country, the number of people, the number of direct investments on both sides, etc. (Figure 7).

1) The effect of the absolute value of the difference in GDP between the two sides of trade on trade flows is modeled as:

$$
\ln T_{i j}=\alpha_{1}+\alpha_{2} \ln G D P_{i}+\alpha_{3} \ln G D P_{j}+\alpha_{4} \ln G_{i j}+\mu
$$

Of which, $T_{i j}$ is the explanatory variable, representing the total exports and imports of both countries, while $G_{i j}$ is the absolute difference in GDP between the two sides. In this model, it is considered that the coefficient of GDP of both countries is positive and can promote the volume of trade. And the distance between the two countries has a hindering effect on trade, the greater the distance 


\begin{tabular}{|c|c|c|c|}
\hline $\begin{array}{l}\text { Explanatory } \\
\text { variables }\end{array}$ & Meaning & $\begin{array}{c}\text { Anticipated } \\
\text { symbol }\end{array}$ & $\begin{array}{l}\text { Theory to } \\
\text { explanation }\end{array}$ \\
\hline GDP & GDP & + & $\begin{array}{l}\text { GDP reflects the total size of a } \\
\text { country's economy, and thus the } \\
\text { greater the bilateral trade flows. }\end{array}$ \\
\hline G & $\begin{array}{l}\text { Absolute difference } \\
\text { in GDP between the } \\
\text { two sides of the trade }\end{array}$ & + & $\begin{array}{l}\text { Reflecting the difference in } \\
\text { volume between the two } \\
\text { economies, the greater the gap, } \\
\text { the greater the volume of trade. }\end{array}$ \\
\hline D & $\begin{array}{l}\text { Absolute distance } \\
\text { between the } \\
\text { two capitals }\end{array}$ & - & $\begin{array}{l}\text { It usually represents a high or } \\
\text { low cost of transport and thus } \\
\text { an important deterrent to } \\
\text { trade and investment. }\end{array}$ \\
\hline $\mathrm{P}$ & $\begin{array}{l}\text { Number of } \\
\text { people in } \\
\text { a country }\end{array}$ & + & $\begin{array}{l}\text { The population increased and } \\
\text { with it the volume of trade } \\
\text { between the two sides. }\end{array}$ \\
\hline FDI & FDI & + & $\begin{array}{l}\text { Usually refers to the amount of } \\
\text { direct investment between the } \\
\text { two countries, which increases } \\
\text { with the amount of trade. }\end{array}$ \\
\hline
\end{tabular}

Figure 7. Meaning of explanatory variables, Anticipated symbol and Theory to explanation.

the greater the cost of trade, the more unfavorable to the development of bilateral trade between the two countries. $G_{i j}$ refers to the absolute difference between the GDP of the two trading parties, the larger the difference in the volume of the economy, the more it will have a positive effect on trade promotion.

2) The effect of population growth on trade flows on both sides of the trade is modeled as:

$$
\ln T_{i j}=\alpha_{1}+\alpha_{2} \ln G D P_{i}+\alpha_{3} \ln G D P_{j}+\alpha_{4} \ln D_{i j}+\alpha_{5} \ln P_{i}+\alpha_{6} \ln P_{j}+\mu
$$

where the sign meanings of GDP and distance D are the same as in (1). $P_{i}$ denotes the number of people in countries with which China trades and the estimated sign should be positive, i.e., the trade volume between the two sides increases when the population increases; $P_{j}$ denotes the number of people in China, and the estimated sign is also positive, i.e., when the population increases, the trade volume between the two sides also increases, which has a positive contribution to the bilateral trade volume.

3) The impact of bilateral FDI on trade flows is modeled as:

$$
\ln T_{i j}=\alpha_{1}+\alpha_{2} \ln G D P_{i}+\alpha_{3} \ln G D P_{j}+\alpha_{4} \ln D_{i j}+\alpha_{5} \ln F D I_{i}+\alpha_{6} \ln F D I_{j}+\mu
$$

The bilateral cross-border direct investment between the two countries is added as an explanatory variable based on the original GNP and the distance D between the two countries. Where $F D I_{i}$ refers to the amount of direct investment from the investing country to China, and the estimated sign should be positive, i.e., an increase in the amount of mutual investment between the two countries will increase the trade volume between the two countries, i.e., it has a positive contribution to the bilateral trade volume. 


\subsection{Model Analysis}

The regression analysis based on the gravity model leads to the following.

1) GDP on trade is a positive role in promoting; the expansion of the GDP of the two countries will lead to an increase in national income, the disposable income of residents increased, as residents will increase the demand for domestic or foreign products, increased demand thus stimulating the growth of bilateral trade.

2) The distance between the two countries on trade for the reverse role, the more distant the two countries, transport costs increase, leading to an increase in bilateral trade costs, and subsequently will reduce bilateral trade behavior, reducing the volume of bilateral trade.

3) The absolute value of the difference between the GDP of the two countries has a positive effect on bilateral trade volume, the greater the difference between the bilateral GDP, the greater the economic gap between the two trading parties, the products between the two countries will show complementarity in terms of supply, promoting the development of bilateral trade.

4) Bilateral direct investment also has a positive promotion effect on bilateral trade. The larger the amount of direct investment between the two countries is, the more active the economic cooperation activities between the two countries are, which in turn stimulates the growth of bilateral trade.

Accordingly, the classification criteria for trade potential: the trade potential is estimated using the ratio of actual and forecasted values, and the trade potential values can be classified into three: potential huge, potential growth and potential mature. Based on the trade gravity model, we can make a brief analysis of trade potential between China and Russia. The ratio of actual trade to forecasted trade between China and Russia fluctuates smoothly around 1, which can be seen as potential growth type, and bilateral trade still has a large scope for expansion. On the basis of continuing to maintain the original bilateral scale, we can further expand bilateral trade by actively cultivating new trade growth points and developing diversified trade patterns.

\section{Countermeasure Suggestions for the Development of China-Russia Trade Potential}

In the post-financial crisis period, bilateral trade between Russia and China has grown tremendously, and both sides are aware of the important role of strengthening bilateral trade and economic cooperation in coping with the financial crisis, initiating economic recovery and accelerating economic development. However, there are still some problems: First, the volume of bilateral trade between Russia and China is low when compared with the United States, Japan, Hong Kong, Germany and other regions, which does not take advantage of the location between Russia and China. Secondly, although the bilateral trade between China and Russia is complementary, the structure of Russia's exports to China is relatively homogeneous, most of which are resources and energy, while the technological content of China's exports to Russia is low and they are all la- 
bor-intensive products. As for the problems of bilateral trade between Russia and China, the following suggestions are made to enhance the potential of bilateral trade between Russia and China.

\subsection{Deepening Regional Cooperation}

The establishment of APEC has given a clear impetus to bilateral trade between China and Russia. On this basis, China and Russia should further deepen regional cooperation mechanisms to promote the rapid development of bilateral trade. Based on the institutional guarantees of bilateral trade, the two sides should deepen cooperation in multilateral frameworks such as the United Nations, G20, BRICS mechanism, SCO and ASCC, establish a free trade zone, reduce trade barriers, and solidify trade relations between the two sides, so that China and Russia will have increasingly stronger economic ties.

\subsection{Enabling Economic Scale}

The scale of economy influences GDP per capita, and the increase of these two factors is an important indicator for promoting bilateral trade flows, so promoting the scale of economy and constantly increasing GDP per capita is conducive to improving the development of bilateral trade between Russia and China. Therefore, the government should help to scale up the economy, optimize the industrial structure, increase the degree of opening to the outside world, accelerate modernization while developing the domestic economy, and constantly improve the living standards of the people, which are fundamental measures to tap the potential of bilateral trade.

\subsection{Restructuring of Bilateral Trade}

China and Russia should continue to take advantage of their comparative advantages by using advantageous industries, give full play to the complementarity of bilateral trade, and go to a higher level on the original basis. For Russia, minerals, fuels, steel and other products have obvious comparative advantages; for China, clothing, textiles and electronic products have comparative advantages. Using the complementarity of comparative advantage products, we should adjust the bilateral trade structure and increase bilateral trade cooperation. However, at the same time, China also needs to reduce its dependence on Russian energy products such as oil and gas. Russia has an absolute advantage in energy products, which gives it an advantage in international strategic issues and other areas. Rapid economic development has increased China's dependence on oil resources, which can be detrimental to China's economic and strategic security. Cooperation between Russia and China should be more diversified, jointly promoting the development of cooperation in the fields of e-commerce, biomedicine, aviation and military industry.

\section{Concluding Remark}

China-Russia comprehensive strategic cooperative partnership in the new era is 
all-around, multi-level, strong dynamic and long-period. China and Russia have stabilized and developed Sino-Russian trade relations by relying on the two countries' economic complementarities and by virtue of their unique geographical locations and other favorable conditions. On the whole, China and Russia have great potential for bilateral trade, and both sides should strengthen trade cooperation, cultivate new trade growth points and develop bilateral trade potential in this year of science and technology innovation in China and Russia.

\section{Conflicts of Interest}

The authors declare no conflicts of interest regarding the publication of this paper.

\section{References}

Gao, L. (2008). Research on China-Russia Trade Based on Gravity Model. Shenyang University of Technology.

Huang, X. G. (2016). Exploration of the Current Situation and Potential of Sino-Russian Trade under the Implementation of the Belt and Road Strategy. Henan University of Economics, Political Science and Law.

Li, B., \& Yu, S. B. (2018). Analysis of Trade Potential between China and Russia in the Context of "One Belt, One Road" and Countermeasures Research. Mall Modernization, No. 6, 63-64.

Lin, L., \& Wang, Y. (2004). Empirical Test and Policy Implications of Trade Gravity Model for China's Bilateral Trade. Word Economy Studies, No. 7, 54-58.

Liu, S. H., \& Yin, J. Z. (2016). Analysis of Trade Development Characteristics and Countermeasures between China and Russia. Foreign Economic \& Trade, No. 7, 44-46.

Sheng, B., \& Liao, M. Z. (2004). China's Trade Flows and Export Potential: A Study of the Gravity Model. The Journal of World Economy, No. 2, 3-12.

Sun, Z. Z. (2020). Empowering China-Russia Relations in the New Era. World Knowledge, No. 11, 25-27.

Wan, Y. K. (2017). Analysis of the Potential of China-Russia Trade Cooperation in the Context of the Construction of the Silk Road Economic Belt. Journal of Lanzhou University (Social Science), 45, 139-145.

Xu, B. L., \& Na, Z. F. (2018). Trade Potential and the Ceiling and Growth Space of Sino-Russian Economic and Trade Cooperation. Journal of Shanghai University (Social Science), 35, 1-16.

Yang, Y. M. (2009). Research on the Development of China-Russia Trade, Influencing Factors and Countermeasures. Ocean University of China. 